Sahetapy, Y., Susana, P., \& Kristijanto, A. I., (2020). Hardiness: Pengalaman pengasingan perempuan wambon pada saat melahirkan dan masa nifas. Indigenous: Jurnal Ilmiah Psikologi, 5(1). 103-118. doi: http://dx.doi.org/10.23917/indigenous.v5i1.11069

\title{
Hardiness: Pengalaman Pengasingan Perempuan Wambon Pada Saat Melahirkan dan Masa Nifas
}

\author{
Yanadelle Sahetapy $^{1}$, Susana Prapunoto ${ }^{2}$, A. Ign. Kristijanto ${ }^{3}$ \\ Fakultas Psikologi, Universitas Kristen Satya Wacana ${ }^{1,2,3}$ \\ yanadelle@gmail.com', prapunoto2007@gmail.com², \\ gus_ign111@yahoo.co.id ${ }^{3}$
}

\begin{abstract}
Abstrak. Penelitian ini bertujuan untuk mendeskripsikan pengalaman perempuan Wambon yang membentuk ketangguhan (hardiness) saat pengasingan ketika melahirkan di Bevak dan dan masa nifas di tempat pengasingan (Dogap). Sebuah fenomena yang terkait erat dengan adat istiadat dan penghargaan budaya, yang diwariskan secara turun temurun. Unit analisis adalah empat subjek yang terdiri atas satu perempuan primipara, satu perempuan multipara dan dua perempuan grandemulitipara. Metode kualitatif digunakan dengan pendekatan interpretative phenomenological analysis dan indigenous psychology digunakan untuk menganalisis kedalaman konkes maupun konten pengalaman fenomenal tersebut. Pengambilan data dilakukan dengan wawancara mendalam dan semi-terstruktur, observasi, dan live in. Hasil penelitian menunjukkan bahwa subjek mengalami tekanan psikologis dalam upaya persalinan dan pada saat pengasingan. Namun demikian, subjek memaknai pengalaman pengasingan sebagai pengalaman yang positif dan menjadi semakin tangguh (hardiness) dalam menjalani tradisi tersebut. Nilai-nilai spiritual dan buday lokalyang diwariskan turun-temurun ditemukan berkontribusi bagi subjek di dalam mengatasi beban psikologis di dalam pengasingan sehingga terbentuk sikap yang tangguh (hardiness). Ketangguhan tersebut dimaknai sebagai upaya menuju kesejahteraan keluarga.
\end{abstract}

Katakunci: : hardiness; pengasingan; perempuan Wambon; melahirkan; nifas

Abstract. This study aims to describe the experience of the Wambon woman who forms hardiness during exile when give birth in the Bevak and postpartum at Dogap. A phenomenon related to customs and respect for culture which is inherited from generation to generation. The unit of analysis consists of four subject. One primiparous woman, one multiparous woman and two grandmultiparous woman. Qualitative Methods with Interpretative Phenomenological Analyis and Indigenous psychology approaches using to analyze the depth of context and content of the phenomenal experience. Data was collected by in-dept interviews and semi structured, participant observations and live in. This research findings of this was the subject experiencing psychologic stress level in the effort of giving birth and exile. However the subject interpreted the experience of exile as a positive experience and become more hardiness in undergoing the tradition. Spiritual values and local cultures passed down from generation to generation were found to contribute to the subject in overcoming psychological burden in exile thus forming hardiness. Hardiness interpreted as an effort towards family welfare.

Keywords : hardiness; exil; Wambon woman; give birth; postpartum 


\section{PENDAHULUAN}

Peraturan Pemerintah Nomor 78 Tahun 2014 tentang Percepatan Pembangunan Daerah Tertinggal, dan Peraturan Presiden Nomor 131 Tahun 2015 tentang Penetapan Daerah Tertinggal Tahun 2015 - 2019 telah menetapkan Boven Digoel sebagai salah satu kabupaten yang memerlukan upaya peningkatan kualitas dibandingkan dengan daerah lain dalam skala nasional. Boven Digoel adalah salah satu kabupaten di Papua yang baerkedudukan di Tanah Merah. Kabupaten Boven Digoel didiami oleh 3 etnis besar yaitu suku Wambon (Mandobo), suku Muyu dan Awuyu. Suku Wambon (Mandobo) yang menjadi perhatian peneliti mendiami daerah antara sungai Digul dan Sungai Kao. Wilayahnya meliputi distrik Manggelum dan Distrik Mandobo (Laksono, 2014).

Tiap-tiap daerah memiliki keunikan karakter budaya sendiri-sendiri. Schultz \& Schultz dalam Rahman, (2017) menyatakan bahwa karakteristik budaya yang berbeda akan membentuk karakteristik psikologis dan kepribadian yang berbeda pula. Oleh karena itu, dalam memahami perilaku perempuan Wambon yang menjalani tradisi pengasingan, diperlukan cara pandang dengan bingkai acuan yang dibangun dari konteks masyarakat setempat atau bersifat pribumi yaitu psikologi Indigenous sebagai kajian ilmiah mengenai perilaku dan mental manusia yang bersifat pribumi, tidak dibawa dari daerah lain, dan didesain untuk masyarakatnya sendiri (Kim \& Berry, 1993). Salah satu karakteristik psikologi indigineous adalah penelaahan fenomena psikologis individu dalam konteks keluarga (Kim, Yang \& Hwang, dalam Hakim 2014).

Keluarga sebagai lembaga pendidikan utama memiliki sistem kekerabatan dan organisasi sosial. Keluarga etnis Wambon sebagai manusia berbudaya sangat berpegang teguh pada nilainilai budaya yang diwariskan leluhur hingga kini. Salah satu budaya yang masih dipertahankan adalah pengasingan perempuan baik pada saat menstruasi, melahirkan maupun masa nifas. Budaya pengasingan perempuan merupakan warisan turun-temurun dan diterima sebagai sesuatu yang memiliki nilai tersendiri karena berkaitan dengan kepercayaan terhadap alam supranatural. Ada hal mistis dan berakar kuat, bahwa darah menstruasi dan persalinan serta nifas akan mengakibatkan hilangnya kesaktian laki-laki bahkan membawa malapetaka seperti menderita penyakit tertentu hingga kematian (Schoorl, dalam Laksono 2014).

Ketaatan terhadap ritual budaya turun temurun terkesan tidak memedulikan perilaku standar kesehatan maternal, yang berdampak pada keselamatan ibu maupun bayi. Biro Komunikasi dan Pelayanan Masyarakat Kementrian Kesehatan Republik Indonesia menginformasikan bahwa angka kematian bayi hingga semester pertama di tahun 2017 tercatat 10.294 kasus kematian, sedangkan angka kematian ibu saat proses persalinan adalah 1.712 kasus. Hasil riset yang dituangkan dalam buku profil kesehatan propinsi Papua tahun 2016 menunjukkan angka kematian bayi per seribu kelahiran hidup mencapai 236 bayi, dan jumlah kematian ibu adalah 72 orang. Kematian bayi maupun ibu disebabkan oleh penanganan kesehatan yang tidak memadai, tambahan pula didukung oleh tingkat pendidikan minim serta faktor kepercayaan dan pengetahuan budaya tentang kesehatan maternal. Hasil penelitian budaya persalinan suku Amungme dan suku Kamoro, Papua yang dilakukan oleh Alwi, Ghani dan Delima (2009) menunjukkan bahwa hampir separuh ibu melahirkan tidak dapat ditolong oleh petugas kesehatan. Persalinan dilakukan sendiri dan perilaku persalinan masih kuat didasari oleh tema budaya yang merugikan kesehatan ibu dan bayi. Kaum pria beranggapan bahwa persalinan sepenuhnya merupakan urusan perempuan dan dianggap sebagai sesuatu yang menjijikkan, serta dapat membawa resiko berbahaya bagi laki-laki. Selain itu, kematian ibu dan bayi juga dianggap sebagai kutukan. 
Beberapa penelitian kesehatan maternal perempuan dalam pengasingan telah dilakukan. Hasil penelitian Dayaksini (2012) menunjukkan bahwa sensasi, persepsi, dan kognisi seseorang sangat dipengaruhi oleh latar belakang budaya yang dilakukan dan telah dipraktikkan secara turun temurun. Lebih lanjut, kajian Laksono, Soerachman dan Angkasawati (2016), menegaskan keyakinan masyarakat, bahwa hawa darah menstruasi maupun persalinan dianggap oleh masyarakat dapat melemahkan dan menghilangkan kesaktian laki-laki, sehingga tradisi pengasingan perempuan harus dilakukan. Bagi yang tidak melakukan tradisi tersebut akan diberlakukan denda adat. Hasil penelitian Ipa, Prasetyo dan Kasnodihardjo (2016) terkait praktik budaya dan perawatan kehamilan, persalinan, dan nifas pada etnik Baduy juga menunjukkan adanya praktik budaya sebagai pendukung kepatuhan terhadap tokoh adat (kokolot). Tidak ada pemeriksaan medis selama masa kehamilan, persalinan, maupun masa nifas. Prosesi melahirkan di tempat persalinan yang kurang memadai, dilaksanakan secara mandiri dengan cara-cara tradisional yang membahayakan. Terdapat larangan bagi perempuan untuk menggunakan pakaian dalam dan pembalut wanita, dan pada saat perempuan hamil maupun pasca persalinan diizinkan melakukan aktivitas berat.

Persoalan pengasingan ini telah dikaji oleh peneliti sebelumnya dan terbatas pada aspek kesehatan fisik, sedangkan kajian mengenai aspek psikologis perempuan Primigravida dan Multigravida terkait pengalaman pengasingan khususnya di distrik Manggelum dan Mandobo belum pernah dilakukan sebelumnya.

Rumusan masalah dalam penelitian ini adalah (1) Bagaimana pendekatan impresif dalam pengalaman psikologis perempuan Wambon dalam budaya pengasingan dikaji? (2) Bagaimana penghayatan spiritual indigenous dapat membantu perempuan Wambon memaknai pengalaman pengasingannya? (3) Bagaimana pada akhirnya menjadikan perempuan Wambon menjadi tangguh (hardiness) dan mampu bertahan dalam penderitaannya? Kajian ini diperlukan untuk menemukan nilai-nilai positif perempuan Wambon dalam memaknai pengasingannya, khususnya hardiness guna mencapai kesejahteraan psikologis sehingga mampu bertahan dalam penderitaan untuk memberikan yang terbaik bagi keluarganya.

\section{METODE}

Penelitian ini menggunakan metode kualitatif fenomenologi humanistik eksistensial untuk mengeksplorasi pengalaman subjek primigravida dan multigravida, serta memahami dinamika psikologi perempuan Wambon dalam pengasingan. Martin Packer (dalam La Kahija, 2017) mendefinisikan fenomenologi sebagai penelitian reflektif tentang inti dari kesadaran yang dialami menurut perspektif orang pertama. Smith, Flowers \& Larkin (dalam La Kahija 2017) mendefinisikan fenomenologi sebagai pendekatan filosofis mengenai pengalaman pengasingan. Penelitian ini menggunakan prinsip dasar dengan mengeksplorasi pengalaman subjek kajian sebagai sumber primer dan didukung oleh data sekunder dari tokoh masyarakat, tokoh adat, dan tokoh agama. Dalam penelitian ini epoche diperlukan karena perlu pemahaman mendalam yang dilakukan agar pengalaman eksistensial dapat diungkapkan.

Pengambilan data dilakukan dengan wawancara mendalam dan semi-terstruktur, observasi, dan live in. Subjek dalam penelitian ini berjumlah empat orang dengan kategori tiga perempuan multigravida dan satu perempuan primigravida. Subjek kajian pertama (multigravida) di kampung Mangga Tiga (distrik Manggelum); subjek kajian kedua (multigravida) di kampung Sokanggo distrik Mandobo-Tanah Merah. Subjek kajian ketiga (multigravida) di kampung Kewam (distrik Manggelum); sedang subjek kajian keempat (p rimigravida) di kampung Bayanggop, (distrik Manggelum) berbatasan dengan Pegunungan Bintang. Wawancara diawali dengan pengisian 
informed consent. Selain itu, wawancara juga dilakukan terhadap empat tokoh masyarakat yaitu tokoh agama, tokoh adat, dan tokoh masyarakat. Data yang diperoleh digunakan sebagai data sekunder, sekaligus untuk mendukung proses triangulasi. Peneliti menganalisis data dengan mengunakan pendekatan Interpretative Phenomenological Analiysis (IPA) yang dikembangkan oleh Smith (dalam Smith, Flowers dan Larkin, 2009). Tujuannya untuk mengeksplorasi makna pengalaman pengasingan perempuan Wambon dalam pengasingan bagi hidupannya.

\section{HASIL DAN PEMBAHASAN}

Untuk memahami kondisi subjek kajian dan data demografi pada tabel 1, 2, dan 3 berikut ini diharapkan dapat memperjelas pemahaman mengenai latar belakang situasi sosial, latar belakang subjek kajian maupun pengalaman, reaksi emosional dan interaksi sosial perempuan Wambon yang menjalani pengasingan. Tabel 1 menjelaskan mengenai data demografi subjek kajian.

Tabel 1.

Data Demografi Subjek Kajian

\begin{tabular}{|c|c|c|}
\hline Kategori & Subjek Multigravida 1 & Subjek Multigravida 2 \\
\hline Pseudonim & Yakoba & Helda \\
\hline Pendidikan & Tidak sekolah & Tidak sekolah \\
\hline Pekerjaan & Petani/IRT & Petani/IRT \\
\hline Agama & Protestan & Katolik \\
\hline Asal & Mangga Tiga-Manggelum & Sokanggo-Mandobo \\
\hline Usia nikah & 15 & 14 \\
\hline Usia Sekarang & 27 & 30 \\
\hline Jumlah anak & 7 & 8 \\
\hline Jumlah meninggal & 1 & 3 \\
\hline Jenis rumah pengasingan & Terpisah dari rumah induk & Rumah Pohon \\
\hline Latar belakang & $\begin{array}{l}\text { Melahirkan di rumput. } \\
\text { Anak pertama dari tiga bersaudara; } \\
\text { Kesulitan ekonomi yang dialami } \\
\text { membuat subjek hanya mampu makan } \\
\text { satu hari sekali. }\end{array}$ & $\begin{array}{l}\text { Satu minggu setelah melahirkan sudah } \\
\text { pergi ke kebun untuk mencari nafkah; } \\
\text { anak pertama dari } 6 \text { bersaudara; Kesulitan } \\
\text { ekonomi yang dialami membuat subjek } \\
\text { hanya mampu makan satu hari sekali. }\end{array}$ \\
\hline Kategori & Subjek Multigravida 3 & Subjek Primigravida 4 \\
\hline Pseudonim & Yomima & Yohanna \\
\hline Pendidikan & SD & SD \\
\hline Pekerjaan & Petani/IRT & Petani/IRT \\
\hline Agama & Protestan & Protestan \\
\hline Asal & Kewam-Manggelum & Bayanggop-Manggelum \\
\hline Usia nikah & 20 & 14 \\
\hline Usia Sekarang & 32 & 18 \\
\hline Jumlah anak & 4 & 1 \\
\hline Jumlah meninggal & 1 & 1 \\
\hline Jenis rumah pengasingan & Terpisah dari rumah induk & Terpisah dari rumah induk \\
\hline Latar belakang & $\begin{array}{l}\text { Masalah poligami; anak bungsu dari } 2 \\
\text { bersaudara. }\end{array}$ & Yatim piatu; anak bungsu dari 2 bersaudara. \\
\hline
\end{tabular}

106 | Hardiness: pengalaman pengasingan ... 
Tabel 1 menunjukkan tingkat pendidikan subjek primigravida dan multigravida yang rendah. Salah satu faktor penyebab rendahnya pendidikan subjek adalah faktor ekonomi. Badan Pusat Statistik (2017) mencatat bahwa terdapat 14 provinsi di Indonesia dengan capaian rata-rata lama sekolah lebih rendah dari capaian nasional. Provinsi Papua hanya mencapai 6,4 tahun dari wajib belajar 12 tahun. Data menunjukkan adanya kesenjangan terkait kualitas guru dan penyediaan sarana dan prasarana sekolah. Rataan Uji Kompetensi Guru (UKG) di Papua berada di peringkat 31 dengan rataan nilai 49,09 dari rata-rata nasional 56,69 pada tahun 2017, artinya berada di bawah standar kompetensi minimal 80, dari rataan nasional UKG. Alfiyah (2010) menyatakan bahwa pendidikan merupakan salah satu faktor penyebab kecenderungan perkawinan usia dini, sebagaimana ditemukan dalam tradisi pengasingan perempuan Wambon. Sarwono (dalam Desiyanti, 2015) menambahkan bahwa tingkat pendidikan dan tingkat kematangan psikososial turut memengaruhi proses pengambilan keputusan di tengah persoalan hidup yang kompleks. Selain itu, perempuan Wambon juga tertutup terhadap kehadiran orang baru di lingkungannya. Hal ini disebabkan perasaan sensitif sebagai kaum yang termarjinalkan sehingga mereka amat berhati-hati terhadap orang yang bukan kerabat atau suku lain.

Bagi perempuan Wambon, beban hidup ini memang dapat berakibat pada distress psikologis dan depresi. Untuk menurunkan distress dan depresi maka dilakukan pendekatan spiritual and religious coping. Masayarakat etnis Wambon masih menganggap laki-laki lebih memiliki derajat lebih tinggi dibanding perempuan. Selain itu, masalah ekonomi juga merupakan beban hidup yang berat pada perempuan Wambon. Beban hidup yang berat tersebut berimplikasi terhadap distress psikologis dan depresi. Namun demikian, perempuan Wambon mengatasi dengan cara spiritual and religious coping. Pemahaman nilai-nilai keagamaan dan keyakinan terhadap apa yang dikatakan oleh Kitab Suci membuat perempuan Wambon tetap berjuang untuk melanjutkan kehidupan mereka, khususnya dalam mengatasi beban hidup yang berat. Kemampuan dalam mengatasi beban hidup tersebut menjadikan perempuan Wambon menjadi tangguh bahkan mampu mencari uang sendiri untuk mengatasi masalah ekonomi dan melawan stigma masyarakat yang memarjinalkan mereka. Hal ini senada dengan pendapat Curtis, Morgan, \& Laird (2018) yang menyatakan bahwa para ibu dengan etnis Negro dan Latin yang termarjinalkan di Amerika Serikat menggunakan spiritual and religious coping untuk menurunkan depresi yang dialami. Tabel 2 menunjukkan gambaran informan dari penelitian ini yang merupakan subjek sekunder.

\section{Deskripsi Pengetahuan Subjek Primigravida dan Multigravida Tentang Tradisi Pengasingan.}

Pengetahuan tentang tradisi pengasingan pada saat persalinan, diketahui dan dipelajari subjek dari ibu mereka, tua-tua adat, dan kerabat terdekat lainnya. Pengetahuan tentang fasilitas bantuan kesehatan melalui Puskesmas baru disosialisasikan sejak awal tahun 2018. Sebelumnya semua perempuan etnis Wambon di distrik Manggelum wajib melahirkan di Bevak. Apalagi di wilayah Bayanggop tidak terdapat Puskesmas. Perjalanan menuju Puskesmas bila ditempuh dengan jalan kaki kurang lebih 2 jam menggunakan perahu (long boat) namun dana yang diperlukan untuk itu cukup mahal menurut ukuran mereka. Faktor ekonomi, sebagaimana diidentifikasi melalui kehidupan masyarakat Wambon yang berada di bawah garis kemiskinan, membuat masyarakat berpikir dua kali untuk melakukan perjalanan yang jauh ke Puskesmas. Perjalanan yang jauh dan melelahkan ini kemudian membuat perempuan Bayanggop umumnya memutuskan untuk melakukan persalinan sendiri di Bevak. Sekalipun pelayanan kesehatan telah disediakan oleh pemerintah, namun menurut dokter Puskesmas, perempuan etnis Wambon lebih memilih melahirkan di Bevak dari pada di Puskesmas. Para subjek berpendapat bahwa bila mereka melahirkan di Puskesmas atau di Rumah Sakit, mereka akan mengalami kesialan, seperti tidak dapat bekerja dalam waktu dekat. Selain itu, 
mereka memiliki pandangan, bahwa melahirkan dengan membuka paha di hadapan orang lain

Tabel 2.

Identitas, Pendidikan, dan Pekerjaan Subjek Sekunder

\begin{tabular}{|c|c|c|c|}
\hline Data/Identitas & Tokoh Adat \& Agama & Petugas Puskesmas & Ortu, saudara, suami \\
\hline \multirow[t]{3}{*}{ Nama } & 1. Paulus & Rangga (Pseudonim) & 1. Juni \\
\hline & 2. Berto (Pseudonim) & & 2. Lukas \\
\hline & & & 3. Max \\
\hline \multirow[t]{3}{*}{ Usia(tahun) } & 1. 40 tahun & $35 \mathrm{Thn}$ & 1. 52 tahun \\
\hline & 2. 50 tahun & & 2. 40 tahun \\
\hline & & & 3. 41 tahun \\
\hline \multirow[t]{3}{*}{ Pendidikan terakhir } & 1. SD & S2 & 1. $\mathrm{SD}$ \\
\hline & 2. Sarjana Muda & & 2. SD \\
\hline & & & 3. SD \\
\hline \multirow[t]{3}{*}{ Agama } & 1. Protestan & Protestan & 1. Protestan \\
\hline & 2. Protestan & & 2. Katolik \\
\hline & & & 3. Protestan \\
\hline \multirow[t]{3}{*}{ Asal } & 1. Bayanggop & Sanger & 1. Bayanggop \\
\hline & 2. Manggelum & & 2. Manggelum \\
\hline & & & 3. Mandobo \\
\hline \multirow[t]{3}{*}{ Pekerjaan } & 1. Petani & PNS & 1. Petani \\
\hline & 2. Rohaniawan & & 2. Petani \\
\hline & & & 3. Petani \\
\hline \multirow[t]{3}{*}{ Jumlah anak } & 1.4 & 2 & 1.6 \\
\hline & 2.3 & & 2.2 \\
\hline & & & 3.5 \\
\hline
\end{tabular}

adalah tabu dan menyinggung harga diri mereka. Selain itu, mereka memiliki pandangan, bahwa melahirkan dengan membuka paha di hadapan orang lain adalah tabu dan menyinggung harga diri mereka. Sebaliknya, mereka berkeyakinan bila proses persalinan dilakukan di bevak, maka dapat ditangani dengan cepat dan lancar. Para subjek mengaku bahwa konsistensi mereka dalam mempertahankan hal tersebut merupakan bagian dari cara alam membentuk mereka menjadi pribadi yang tangguh. Aspek spiritual terkait pengetahuan mengenai adanya kekuatan gaib atau alam supranatural terus dipelihara dengan ketaatan sebagai anggota masyarakat yang berbudaya. Persalinan yang oleh mereka disebut sebagai "menderita" adalah kodrat yang harus dijalani.

Sementara itu sosialisasi yang dilakukan di wilayah yang terdapat Puskesmas, seperti kampung Manggelum dan Sokanggo, adalah seputar penggunaan fasilitas kesehatan yang disediakan pemerintah. Namun sayangnya, masyarakat belum merespon sosialisasi tersebut dengan baik, sehingga masih menjalankan tradisi pengasingan dan persalinan dengan caranya sendiri. Selain itu, masyarakat juga percaya bahwa pelanggaran terhadap tradisi ini justru dapat mengakibatkan sakit bagi keluarga seperti batuk, hosa (asma), TBC dan penderitaan bagi ibu yang akan bersalin. Akibatnya, untuk mengantisipasi hal yang tidak diharapkan, atau situasi sulit, masyarakat umumnya berupaya mencari tahu melalui hal yang supranatural, misalnya dengan mendatangkan dukun. Dyne (dalam Widyarini, 2014) menyatakan bahwa seseorang disebut cerdas secara budaya ditentukan oleh faktor pengetahuannya tentang institusi kultural, norma-norma, dan praktik-praktik yang 
membentuk pola perilaku secara kontekstual. Perempuan Wambon menerima praktik budaya dari warisan leluhur. Orang akan memiliki wawasan pengetahuan yang mumpuni bila fasilitas belajar terpenuhi dengan baik, padahal di distrik Manggelum khususnya di daerah Bayanggop hanya ada satu Sekolah Dasar dengan tiga ruangan belajar. Lama masa sekolah rata-rata adalah tiga sampai empat tahun dan pada tahun 2017 baru dibuka kelas lima dan enam, masing-masing hanya ada dua siswa. Dengan demikian, jelas bahwa pada daerah Manggelum, lama masa sekolah masih lebih rendah dibanding rata-rata Papua yaitu 6,4 tahun dari wajib belajar 12 tahun. Rendahnya tingkat dan kualitas pendidikan berdampak pada kepercayaan pada mitos dan pemahaman tentang perilaku sehat yang perlu diperbaiki. Selain itu, pandangan masyarakat mengenai perkawinan dini dan cara menghadapi kesulitan hidup yang beresiko pada kesehatan ibu dan bayi juga merupakan sebuah fakta yang harus mendapat perhatian serius.

Hakim (2014) menyatakan bahwa untuk memahami manusia tidak boleh melepaskan konteks munculnya perilaku tersebut. Pemikiran ini didasarkan pada apa yang disebut sebagai Indigenous Psychology Approach. Ruml (2016) menyebutkan bahwa ada perbedaan pandangan mengenai kesehatan pada masyarakat pribumi yang mempertahankan pendekatan spiritual sebagai penyembuhan dan masyarakat nonpribumi yang menggunakan pendekatan medis. Menurut Kim, Yang \& Hwang (2006), masyarakat pribumi dan nonpribumi mengangap satu dengan yang lain aneh/bodoh. Masyarakat pribumi memandang fenomena secara kontekstual dan bukan arus utama. Psikologi indigenous menekankan kajian atas pengetahuan, ketrampilan dan nilai yang dimiliki oleh orang-orang yang mengenal dirinya. Semua itu memberi kontribusi dalam proses mental di tengahtengah konteks keluarga, pangan, sosial, dan kesehatan. Ketika berhadapan dengan tantangan pengasingan, perempuan Wambon memahami fenomena dari pengalaman belajar sesuai dengan tempatnya. Hasil analisis pengalaman pengasingan, reaksi emosional dan interaksi sosial subjek multigravida dan primigravida disajikan dalam tabel 3 .

Tabel 3.

Pengalaman Subyek Kajian Multigravida 1, 2, 3 dan Primigravida

\begin{tabular}{lll}
\hline Kategori & \multicolumn{1}{c}{ Multigravida 1} & \multicolumn{1}{c}{ Multigravida 2} \\
(Kampung Mangga Tiga) & (Kecamatan/ Distrik Mandobo) \\
\hline Pengalaman Pengasingan & $\begin{array}{l}\text { Bersalin di atas rerumputan, bayinya } \\
\text { meninggal, namun tetap diisolasi di mandiri, kemudian diasingkan di rumah }\end{array}$ \\
& rumah pengasingan sampai dengan masa pohon (dibuat oleh suami dan saudara- \\
& nifas berakhir. Bevak dibuat sendiri, Dogap saudaranya yang lain) hingga masa nifas \\
& dibuat suami. & berakhir. \\
& Merasa sakit, nyeri di punggung bagian Subjek tidak merasa sakit yang berlebihan \\
& belakang. Pada masa pengasingan masih karena baginya rasa sakit ituadalah kodrat. \\
& mengalami kelelahan, karena harus Kebertahanan ini juga membuat subjyek \\
& duduk di lobang yang disediakan untuk dapat melakukan aktivitas dengan pergi ke \\
& menampung darah nifas. Menolak kebun pada masa nifas usia 1 minggu. \\
& menggunakan pembalut, karena takut \\
& pembalutnya dimakan binatang dan \\
& berakibat buruk bagi dirinya sendiri, \\
& maupun kemalangan bagi binatang, \\
& terutama babi yang selama ini harus dijaga. \\
& Pandangan bahwa alam dan binatang \\
& harus dijaga.
\end{tabular}



istri sekretaris kampung harus melahirkan kematian beberapa anak sebelumnya. Rasa di puskesmas. Informasi penanganan takut yang mendalam, jangan-jangan anak di puskesmas menggunakan alat-alat ini juga akan meninggal. Merasa bahagia rumah sakit membuat subjek mengalami saat melihat anak yang dilahirkan selamat. ketegangan, kecemasan dan kegelisahan. Namun, traumatis tidak kunjung hilang. Walau anaknya meninggal, subjek tetap terisolasi di tempat pengasingan dan masih memikirkan kehilangan anaknya.

\begin{tabular}{|c|c|c|}
\hline Kategori & Multigravida 1 & Multigravida 2 \\
\hline Reaksi emosional & $\begin{array}{l}\text { Perasaan sedih terungkap melalui reaksi } \\
\text { menangis dan kurang tidur. Walau } \\
\text { demikian hal berlangsung hanya sebentar } \\
\text { karena subjek akan melanjutkan kembali } \\
\text { aktivitas bekerja mencari nafkah. }\end{array}$ & $\begin{array}{l}\text { Marah atas perbuatan jahat orang/suanggi, } \\
\text { namun kebahagiaan terungkap dalam } \\
\text { komunikasi yang penuh semangat dengan } \\
\text { bayi mungil yang cantik. Berjuang untuk } \\
\text { hidup dan masa depan bayi }\end{array}$ \\
\hline \multirow[t]{2}{*}{ Interaksi Sosial } & $\begin{array}{l}\text { Mengikuti anjuran suami, sehingga pergi } \\
\text { ke puskesmas untuk melahirkan dengan } \\
\text { keadan terpaksa. }\end{array}$ & $\begin{array}{l}\text { Kematian tiga orang anak dipercayai } \\
\text { sebagai perbuatan jahat orang lain melalui } \\
\text { suanggi/hantu. }\end{array}$ \\
\hline & $\begin{array}{l}\text { Memperhatikan pendapat orang pada } \\
\text { umumnya bahwa persalinan tidak boleh } \\
\text { terjadi di rumah induk. Adanya dukungan } \\
\text { dari pihak puskesmas agar dapat } \\
\text { melahirkan di puskesmas, namun subjek } \\
\text { kembali ke rumah dan melahirkan di atas } \\
\text { rerumputan. }\end{array}$ & $\begin{array}{l}\text { Masalahnya adalah soal tanah/dusun } \\
\text { keluarga. }\end{array}$ \\
\hline Pangan dan kesehatan & $\begin{array}{l}\text { Singkong/kasbi, pisang, daun gedi, daun } \\
\text { pakis, ikan sungai adalah bahan makanan } \\
\text { yang dikelola untuk dikomsusi oleh } \\
\text { subjek. Daun gatal digunakan untuk sakit } \\
\text { punggung. Daun jeruk dan batang sereh } \\
\text { untuk keperluan "ukupan". Perapian } \\
\text { untuk menghagatkan badan baik ibu } \\
\text { maupun bayi. Bayi digendong dengan } \\
\text { menggunakan noken/tas khas Papua. }\end{array}$ & $\begin{array}{l}\text { 1. Sagu, sayur katuk dan ulat sagu menjadi } \\
\text { asupan makanan untuk memperlancar air } \\
\text { susu. } \\
\text { 2. Pengasapan bagi bayi sama dengan } \\
\text { subjek pertama. }\end{array}$ \\
\hline
\end{tabular}

Kategori Multigravida 3

(Kampung Kewam, Manggelum)
Primigravida

(Pedalaman Bayanggop)

Pengalaman pengasingan Bersalin di Bevak dan diasingkan di dogap. Bersalin di bevak buatan sendiri dan Bevak dan dogaf dibuat sendiri oleh subjek. diasingkan di dogaf buatan suami.

Pengalaman Biologis Sakit bersalin yang lumrah dialami oleh Merasa sakit yang amat sangat hingga lainnya. Merasa wajar dan tidak perlu mengeluarkan keringat dingin bahkan mengeluh. lemas.

Pengalaman psikologis Merasa depresi, sedih, sakit hati, tidak Sebagai anak yatim piatu merasa sendiri. diperhatikan karena ketika sudah tiba Subjek sangat merindukan pendampingan waktunya untuk melahirkan, suami subjek ibu kandungnya, saudara perempuan menikah lagi. Walau demikian, Subjek dan tetangga perempuan. Selalu berdoa 
untuk melahirkan dengan selamat, dan sehingga merasa kuat untuk menghadapi menjalani masa-masa pengasingan dengan penderitaan.

tekun berdoa.

Reaksi emosional Sewaktu-waktu menangis, marah bila Menangis karena kematian anaknya ingat perbuatan suaminya yang selingkuh namun terus berharap agar Tuhan ketika dia di pengasingan (Informasi dari mengaruniakan lagi pengganti anak yang kerabat) Namun berupaya menjadi kuat pertama.

bila menggendong anaknya dan berusaha untuk memberikan yang terbaik bagi anaknya. Marah dan memendam rasa sakit hati. Selalu berdoa untuk mengatasi kemarahan dan sakit hatinya.

Menangis karena kematian anaknya namun terus berharap agar Tuhan mengaruniakan lagi pengganti anak yang pertama.

\begin{tabular}{|c|c|c|}
\hline Kategori & Multigravida 3 & Primigravida 3 \\
\hline Interaksi Sosial & $\begin{array}{l}\text { Hubungan baik yang tercipta dengan } \\
\text { selingkuhan suaminya, akan dilakukan } \\
\text { demi ketaatan kepada suami supaya } \\
\text { terhindar dari kekerasan suami. Banyak } \\
\text { keluarga atau saudara yang memberikan } \\
\text { dukungan baik dengan nasehat maupun } \\
\text { pendampingan. }\end{array}$ & $\begin{array}{l}\text { 1. Keaktifan yang bersangkutan dalam } \\
\text { kegiatan keagamaan membentuk perilaku } \\
\text { yang dilatarbelakangi oleh ajaran agama } \\
\text { yang dianutnya. } \\
\text { 2. Menderita saat persalinan adalah } \\
\text { konsep keagamaan yang membuatnya siap } \\
\text { dan sabar menanggung derita. } \\
\text { 3. Mengusulkan agar nilai-nilai positif } \\
\text { dari budaya tetap dipertahankan. } \\
\text { 4. Pemeriksaan di puskesmas dan } \\
\text { persalinan diizinkan, asal pengasingan } \\
\text { tetap dilaksanakan. }\end{array}$ \\
\hline $\begin{array}{l}\text { Kebutuhan pangan dan } \\
\text { kesehatan }\end{array}$ & $\begin{array}{l}\text { Keladi, singkong, sagu, ikan sungai, ulat } \\
\text { sagu, sayur-sayuran seperti daun dan } \\
\text { bunga pepaya. }\end{array}$ & $\begin{array}{l}\text { Jantung pisang, daun gedi, daun katuk, } \\
\text { daun pakis, ulat sagu, siri pinang, sagu, } \\
\text { keladi, pisang, rempah-rempah seperti } \\
\text { jahe, daun jeruk dan sereh untuk sauna }\end{array}$ \\
\hline
\end{tabular}

Seperti yang disampaikan pada tabel 3, pengalaman pengasingan baik secara fisik, psikis, spiritual dan budaya merupakan gambaran unik dan menarik terkait subjek kajian dalam mengemban tanggung jawab untuk diri sendiri dan juga keluarganya. Subjek Multigravida 1 mengatakan bahwa sejak awal tahun 2018, pihak Puskesmas sudah menyosialisasikan pentingnya perawatan kesehatan dengan menggunakan fasilitas kesehatan yang baik. Suami subjek merupakan seorang sekretaris kampung sehingga hal tersebut membuat subjek harus memberi contoh dengan mengikuti anjuran suaminya untuk melahirkan di Puskesmas. Ketika merasa waktunya sudah dekat untuk melahirkan, subjek dibawa ke Puskesmas. Namun, tidak begitu lama berada di Puskesmas, subjek meminta izin untuk kembali ke rumah karena subjek sebenarnya tidak merasa nyaman untuk melakukan proses kelahiran di puskesmas. Petugas Puskesmas pun membenarkan hal tersebut ketika diwawancarai, menurut petugas kesehatan, kehadiran subjek di Puskesmas hanya untuk menghormati suaminya 
saja, tetapi pada dasarnya subjek lebih memilih untuk melahirkan di Bevak. Pada akhirnya subjek melahirkan di atas rumput.

Subjek Multigravida 2 menjalani persalinan dengan menolong diri sendiri. Subjek duduk di atas lobang yang sudah dialasi kayu dan pelepah pisang atau batang pohon sagu sebagai tempat menadah bayi yang akan lahir, kemudian memegang tiang dengan kedua tangannya sambil jongkok, ketika bayinya keluar subjek memotong ari-ari dengan menggunakan alat tradisional bambu (wilatJawa) sebagai pengganti pisau. Cara seperti ini menurut dokter Puskesmas merupakan cara yang membahayakan, misalnya, dapat mengakibatkan benturan pada bagian kepala bayi. Selain itu, tempat melahirkan seperti itu tidak bersih dan dapat menimbulkan infeksi pada ibu dan bayi. Menurut Hartini (2009) sangat penting untuk memperhatikan kesehatan bayi dalam proses kelahiran karena hal ini akan menetukan kualitas masa depan anak-anak tersebut. Walaupun sudah tujuh kali menjalani persalinan, namun perasaan traumatis menghantui pikirannya sebab sudah tiga orang anaknya meninggal ketika menjalani proses persalinan di Bevak. Ada kecurigaan bahwa bukan soal menjalankan tradisi pengasingan sebagai penyebab dari kematian anak, melainkan niat jahat orang lain karena urusan tanah atau kebun keluarga. Niat jahat itu terwujud dalam bentuk kiriman "roh jahat" (suanggi-bahasa Papua) yang mematikan anak-anak dari subjek yang bersangkutan. Suanggi diyakini sebagai manusia yang bersekutu dengan roh jahat dan dapat mengakibatkan penderitaan, penyakit, kemalangan, dan bahkan kematian bagi orang lain (Ceme, 2016). Pada sisi lain Nobakht \& Dale (2018) menyatakan bahwa orang-orang yang mengalami pengalaman dekat dengan kematian mempunyai pengalaman mistik atau pengalaman spiritual.

Subjek multigravida 3 sudah mempunyai pengalaman melahirkan di Bevak sebanyak empat kali dengan persoalan suami yang berpoligami. Ketika waktu bersalin sudah mendekat, suaminya membawa masuk perempuan lain dan dijadikan istri kedua serta tinggal bersama-sama dengan mereka. Perasaan sedih, kecewa, sakit hati, harus diterima, dan demi keselamatan bayi yang dikandung, walaupun demikian, subjek berusaha untuk bertahan dalam kondisi tersebut. Kebahagiaan yang didambakannya sebagai seorang istri dan ibu rumah tangga dalam satu keluarga menjadi terganggu. Namun, subjek tetap menguatkan diri sendiri dalam menghadapi cobaan yang dihadapi. Ketekunan berdoa, serta pergi mencari nafkah di kebun adalah aktivitas yang dilakukan subjek untuk mengatasi pergumulan yang dihadapi. Chi (2018) menyatakan bahwa kecintaan akan hubungan interpersonal termasuk dalam keluarga akan meningkatkan kesejahteraan psikologis dan spiritual. Hal ini membuat orang menjadi setia dengan hubungan yang dibangun. Subjek dalam menjalani masa pengasingan tetap berjuang untuk mempertahankan keutuhan keluarga sekalipun harus diduakan pada saat pengasingan.

Subjek primigravida merupakan seorang anak yatim piatu, yang menjalani pengasingan di Dogaf dengan ruangan seluas $2 \times 3$ meter tanpa pintu. Di dekat papan pembaringan ada tungku dengan kayu bakar untuk menghangatkan tubuh. Tidur di papan yang kotor dengan keterbatasan air bersih, dingin, tanpa lampu, namun perempuan primigravida tetap bertahan menjalani pengasingan, melindungi anaknya dengan berselimutkan kain dan pelepah sagu. Hal ini merupakan kondisi yang sangat memprihatinkan bagi kesehatan ibu dan anak. Setelah dua minggu menjalani pengasingan, bayi tersebut meninggal dunia akibat infeksi tali pusat. Nolan (2010) mengatakan bahwa proses persalinan harus diperhatikan dengan baik secara khusus dalam pemotongan dan perawatan tali pusat, sebab akan mengakibatkan infeksi bagi tubuh bayi. Perasaan sedih sebagai anak yatim piatu ditambah beban kehilangan anak pertama yang baru dilahirkan terlihat dalam percakapan ketika subjek mengungkapkan perasaan-perasaannya, namun subjek tetap memiliki harapan hidup dan memaknainya sebagai sebuah persoalan yang diizinkan Tuhan agar dapat bersikap dewasa dalam merespon setiap masalah yang dihadapi. Brown, dkk,.( 2013) menyatakan 
bahwa kecemasan dan depresi yang disebabkan oleh tekanan hidup dapat secara efektif diturunkan melalui religious coping style dan menimbulkan spiritual well-Being. Hal ini terjadi pada subjek primigravida yang mengimani pertolongan Tuhan, sehingga merasa tenang dan nyaman walaupun subjek mengalami penderitaan di pengasingan, yakin bahwa di balik penderitaan itu ada kekuatan, dan penderitaan yang harus dilalui sebagaimana dicatat dalam Kitab Suci.

Secara psikologis, rasa takut dan cemas sering dialami oleh subjek primigravida. Hal ini disebabkan karena pengalaman melahirkan merupakan pengalaman pertamanya. Kecemasan umumnya sering menghantui pikiran subjek primigravida, dengan adanya kepercayaan masyarakat bahwa kondisi sulit dalam proses bersalin juga disebabkan karena ada hal yang tidak beres yang dilakukan oleh ibu. Misalnya, ibu tersebut dicurigai bahwa anak yang dilahirkan merupakan hasil perselingkuhan. Selain itu, juga subjek primigravida cenderung memiliki ketakutan yang berlebihan atas kesehatan anaknya selama menjalani pengasingan di dogav. Kecemasan yang dialami oleh subjek primigravida ditunjukkan melalui penurunan kondisi tubuh selama menjalani pengasingan yang sering kali dialami. Bagi ibu Multigravida, mereka memandang proses persalinan sebagai hal yang biasa dengan melihat pengalaman sebelumnya sebagai proses belajar yang memberikan kenyamanan pada dirinya. Bukan hanya kecemasan, namun ada ketakutan yang dialami oleh para subjek saat menjalani proses melahirkan, bilamana anak yang dilahirkan akan meninggal untuk kesekian kalinya dan rasa takut jika diabaikan oleh suami yang memiliki istri lebih dari satu. Namun, perempuan Wambon tetap bertahan dalam menjalani tradisi pengasingan ini karena mereka percaya bahwa di dalam Kitab Suci juga dijelaskan penderitaan merupakan kodrat yang harus dialami dan dijalani oleh seorang perempuan.

Kenyataan ini sejalan dengan hasil kajian Abdollahi, dkk. (2014) yang menemukan bahwa hardiness dapat menjadi moderator antara stres dan kebahagiaan. Kecerdasan dalam hal hardiness memungkinkan seseorang mengatasi stres lebih baik dan berkontribusi untuk menjadi lebih bahagia. Orang yang memiliki hardiness mampu menilai situasi yang tidak nyaman dan menekan sebagai kondisi tidak stres sehingga dapat merasakan kebahagiaan yang lebih tinggi. Hardiness dan penghayatan religius inilah yang membuat perempuan Wambon mampu bertahan sekalipun menghadapi kondisi tertekan yang berat dalam proses pengasingan.

Ketangguhan hidup (hardiness) seorang perempuan Wambon dalam menjalani proses persalinan hingga masa nifas dalam tradisi pengasingan dijelaskan oleh Cotton (dalam Dodik, 2012) sebagai komitmen diri dalam menciptakan tingkah lakunya yang aktif terhadap lingkungan dan perasaan bermakna tentang diri sendiri yang bertujuan untuk menetralkan efek negatif yang timbul dari stres yang dialami. Lebih lanjut menurut Kreitner, dkk. (2014), Hardiness melibatkan kemampuan seseorang untuk mengubah stressor negatif menjadi sebuah tantangan yang positif (Kobasa). Dengan demikian, berdasarkan hasil penelitian yang telah dideskripsikan, akan dibahas ketangguhan hidup (Hardiness) perempuan Wambon dalam menjalani ritual pengasingan hingga pasca melahirkan yang terbagi dalam tiga dimensi, yaitu kontrol, komitmen, dan challenge.

\section{Dimensi Kontrol}

Kontrol merupakan sebuah ukuran pada ketiadaan kekuatan diri yang dirasakan oleh seseorang, yang dipercayai bahwa ia dapat mengontrol dirinya sendiri ketika mengalami sesuatu, sehingga dapat memodifikasi stresor tersebut untuk mengurangi kecemasan yang berlebihan dalam diri. Perempuan Wambon pada umumnya memiliki kontrol diri yang baik. Hal tersebut disebabkan kepatuhan mereka untuk menjalankan tradisi budaya, mereka lebih memilih melakukan proses persalinan di dalam Bevak daripada di Puskesmas. Persoalan harga diri yang membuat mereka optimis untuk mempertahankan dan berjuang dalam menjalani tradisi budaya pengasingan. 
Kobassa (dalam Smith dan Argiyati, 2013) menyatakan bahwa orang yang memiliki kontrol diri yang baik mampu memengaruhi dirinya sendiri untuk lebih optimis dan memiliki keyakinan atas diri dalam menghadapi hal-hal yang terjadi di luar dirinya. Hal ini juga sejalan dengan Los (2014) yang menyatakan bahwa efikasi diri dan kontrol diri dalam regulasi memengaruhi kemampuan kognitif dan metakognitif. Hal inilah yang membuat seseorang mampu mengelolah lingkungan yang tersedia di sekitarnya, sehingga sekalipun ada beban berat dalam kehidupannya, orang itu akan belajar sejalan dengan waktu mengenai lingkungan yang ada di sekitarnya. Hal ini didukung oleh pengalaman belajar dari orang-orang yang senasib sepenanggungan dengannya. Perempuan Wambon memandang bahwa yang dilakukannya baik, sejalan dengan keyakinan bahwa perempuan harus menderita dalam proses melahirkan.

\section{Dimensi Komitmen}

Komitmen adalah kecenderungan individu untuk melibatkan diri pada keyakinan yang dimiliki. Keyakinan itu diwujudkan melalui perilaku yang bermakna dan memiliki tujuan. Seperti yang dilakukan oleh para subjek yang menjalani tradisi pengasingan di suku Wambon. Meskipun para suami di suku Wambon memaksakan mereka untuk harus melakukan proses persalinan di Puskesmas dan juga berdasarkan peraturan pemerintah tahun 2017 telah menetapkan bahwa proses persalinan dapat dilakukan di Puskesmas terdekat, namun mereka tetap mempertahankan tradisi tersebut, karena keyakinan bahwa warisan budaya harus tetap dijaga, tanpa terpengaruh modernisasi. Keterbatasan pendidikan mereka mengakibatkan adanya pandangan bahwa darah persalinan adalah pembawa sial, proses bersalin yang terbaik hanyalah di Bevak. Ada rasa malu jika persalinan ditolong atau dilihat oleh orang lain, dan adanya pandangan diri sebagai perempuan yang berharga karena mampu berjuang melewati kesulitan, meskipun tidak sedikit bayi yang meninggal selama ibu menjalani proses persalinan di Bevak. Mereka meyakini bahwa ketika mampu menjalani tradisi ini dengan baik, mereka akan menjadi perempuan yang berharga, di mata manusia maupun di mata Tuhan. Hal ini sejalan dengan Kobassa (1982) yang menyatakan bahwa individu yang memiliki komitmen yang kuat tidak akan mudah menyerah pada tekanan

\section{Dimensi Challenge}

Menurut Kobasa (1984) challenge adalah kecenderungan seseorang untuk memandang suatu perubahan dalam hidupnya sebagai hal yang wajar, serta mampu mengantisipasi perubahan tersebut sebagai sebuah stimulus yang berguna bagi diri pribadinya dalam perkembangan ke arah yang lebih baik, dan memandang hidup sebagai sesuatu tantangan yang mengasyikkan. Seperti perempuan Wambon dalam perjuangannya melakukan persalinan sendiri tanpa bantuan siapa pun, mereka berusaha agar anak yang mereka lahirkan tidak meninggal. Namun kenyataannya, beberapa subjek mengalami kematian bayi karena infeksi yang dialami atau juga karena penurunan kondisi fisik sang bayi. Mereka tidak putus asa atau takut untuk memiliki anak sekalipun harus melakukan persalinan sendiri di Bevak. Pengalaman-pengalaman buruk selama persalinan yang pernah dialami oleh para subjek, membuat mereka belajar untuk lebih hati-hati dalam melakukan proses persalinan dan perawatan bayinya. Mereka percaya bahwa jika diberikan anak, itu berarti bahwa mereka diberikan kesempatan lagi oleh Tuhan untuk menjalani tantangan hidup ini dengan baik tanpa harus putus asa atau menyerah dalam melaksanakan setiap tanggung jawab sebagai seorang ibu untuk menjaga keselamatan anak yang dilahirkannya. Individu yang memiliki challenge adalah orang-orang yang dinamis dan memiliki kemampuan serta keinginan untuk kuat bertahan menghadapi segala hal (Salvatore, 2002).

Hal ini sejalan dengan hasil kajian Pordanjani, dkk. (2018) yang menemukan bahwa hardiness 
dan sikap keagamaan masing-masing dapat memprediksi stres kehidupan. Semakin kuat sikap dalam hal keagamaan dan hardiness, stres yang dihadapi semakin lebih rendah. Sejalan dengan itu Jamal, dkk. (2017) juga menemukan hubungan positif yang signifikan antara stres dan penghindaran coping, hardiness, dan coping yang berfokus pada masalah.

\section{SIMPULAN}

Perjuangan hidup dan kebertahanan masyarakat etnis Wambon pada umumnya, menunjukkan adanya ketangguhan hidup yang patut dibanggakan. Ketangguhan bergantung pada karakteristik, kepribadian dan cara pandang seseorang akan hidupnya. Kondisi sulit ketika menjalani tradisi pengasingan diwarnai oleh tingkat kecemasan yang tinggi, rasa takut yang berlebihan, kecewa, dan marah. Namun demikian, ketika subjek menghayati iman akan pertolongan Tuhan (penghayatan religius), kondisi stres mampu diatasi. Dengan demikian, hardiness dan penghayatan spiritual indegenous merupakan faktor utama yang membuat perempuan Wambon mampu bertahan dalam menjalani pengasingan.

Penelitian ini menemukan bahwa keempat subjek menunjukkan adanya kepribadian tangguh (hardiness) yang dimiliki. Kontrol diri dan komitmen perempuan Wambon untuk tetap melakukan tradisi pengasingan, menguatkan mereka dalam mengembangkan kepribadian tangguh (hardiness). Bentuk tingkah laku yang dimunculkan oleh para subjek merupakan gambaran dari pribadi tangguh. Bentuk tingkah laku seperti melahirkan sendiri di Bevak, setelah itu menuju Dogap menjalani ritual pengasingan, merawat diri sendiri dan bayi yang baru dilahirkan tanpa bantuan siapapun, pergi ke kebun mencari makanan untuk dimasak sebagai penunjang gizi selama didalam rumah pengasingan adalah ciri hardiness.

Semua proses mental perempuan Wambon dalam pengasingan dapat diatasi dengan pendekatan spiritual indigenous sebagai formulasi budaya yang membuat mereka tangguh, bertahan di tengah penderitaan dan tetap memaknai hidup mereka dengan baik. Kebertahanan untuk bersalin di Bevak dan diasingkan di Dogafmenunjukkan bentuk ketaatan masyarakat etnis Wambon pada tradisi yang telah turun-temurun dilakukan. Ketaatan ini kemudian membentuk perempuan Wambon menjadi sosok yang tangguh dan terus berjuang untuk keselamatan diri dan bayinya. Kasih kepada bayi dan demi keselamatan dan keutuhan keluarga menjadikan subjek begitu kuat, berjuang menahan sakit, bahkan berupaya untuk memberi yang terbaik bagi bayi yang dilahirkan.

Berdasarkan perspektif psikologi kearifan lokal, peneliti menemukan bahwa kebertahanan dan ketangguhan perempuan Wambon dalam menjalani tradisi dan budaya pengasingan sangat dipengaruhi oleh kontrol, komitmen dan challenge. Namun demikian pada sisi lain terdapat persoalan kesehatan maternal yang terabaikan dan kurang disadari sebagai masalah.

Implikasi dari keadaan ini, para perempuan Wambon tetap memertahankan tradisi yang turun-temurun. Oleh karena itu, peneliti mengusulkan rekomendasi: (1) Kepada Dinas Kesehatan, pimpinan daerah agar memperhatikan kesehatan maternal dan memperhatikan kondisi Bevak dari kaum perempuan etnis Wambon; (2) Dinas Pendidikan agar memperhatikan penyelenggaraan pendidikan dan peningkatan kualitas guru agar terpenuhi delapan standar nasional pendidikan. Selain itu masyarakat harus dipahamkan pentingnya pendidikan informal; (3) Dinas Pemberdayaan Perempuan Perlindungan Anak Pengendalian Penduduk dan Keluarga Berencana agar memperhatikan pentingnya pendampingan terhadap para perempuan yang hamil tua dan pasca persalinan dalam masa pengasingan. Tokoh-tokoh masyarakat dan tokoh adat perlu mendapat pelatihan pendampingan untuk kemudian memberikan penyuluhan melalui wadah pertemuan para ibu di kampung setempat. 


\section{REFERENSI}

Abdollahi, A., Talib, M. A,. Yaacob, S. N., \& Ismail, Z. (2014). Hardiness as a mediator between perceived stress and happiness in nurses. Journal of Psychiatric and Mental Health Nursing, 21 (9), 789-796.

Alfiyah. (2010). Sebab-sebab pernikahan dini. Jakarta: EGC

Alwi, Q., Lannywati, G., \& Delima. (2009). Budaya persalinan suku amungme dan suku Kamoro, Papua. Jurnal Kedokteran Trisakti, 23 (4), 141-149.

Badan Pusat Statistik. (2017). Provinsi Papua dalam Angka tahun 2017. Diunduh pada 7 Agustus 2018.

Brown, D. R., Carney, J. S., Parrish, M. S., \& Klem, J. L. (2013). Assessing spirituality: The relationship between spirituality and mental health. Journal of Spirituality in Mental Health, 15(2), 107-122.

Ceme, R. (2016). Perjuangan melawan stigmatisasi suanggi dalam masyarakat. Jurnal. stiparende. ac.id/ index.php/jar/article/download/7/7. Diunduh 10 Maret 2018.

Chi, M. Y. E., (2018). Loving relationships and a praxis of love. Journal of Spirituality in Mental Health, 1-21, doi: 10.1080/19349637.2018.1547176.

Curtis, C. Morgan, J. \& Laird, L. (2018). Mother's gardens in arid soil : A study of religious and spiritual coping among marginalized U.S. mothers with depression. Journal of Spirituality in Mental Health, 1-28, doi: 10.1080/19349637.2018.1428139.

Dayaksini, Tri \& Salis Y. (2012). Psikologi lintas budaya. Malang: Universitas Muhammadiyah Press.

Desiyanti, I. W. (2015). Faktor-faktor yang berhubungan terhadap pernikahan dini pada pasangan usia subur di Kecamatan Mapanget Kota Manado. Jurnal JIKMU, 5 (2), 270-280.

Dodik, A.A. SS., \& Astuti, K. (2012). Hubungan antara kepribadian hardiness dengan stres kerja pada anggota POLRI bagian operasional di Polresta Yogyakarta. Insight, 10 (1), 37-48.

Hakim, L.N. (2014). Ulasan konsep: pendekatan psikologi indijinus. Jurnal Aspirasi, 5 (2), $165-$ 172.

Ipa, M., Prasetyo, D. V., \& Kasnodihardjo. (2016). Praktik budaya perawatan dalam kehamilan persalinan dan nifas pada etnik Baduy Dalam. Indonesian Journal of Reproductive Health, 7 (1), 25-36.

Jamal, Y., Zahra, S. T., Yaseen, F., \& Nasreen. M. (2017). Coping strategies and hardines s as predictors of stress among rescue workers. Pakistan Journal of Psychological Research, 32 (1), 141-154.

Kim, U. \& Berry, J. W. (1993). Indigenous psychologies: Experience and research in cultural context. Newbury Park, CA : Sage Publication.

Kobasa, S. C. (1979). Stressful life events, personality, and health: An inquiry into hardiness. Journal of personality and Social Psychology, 37 (1), 1-11. 
Kobasa, S. C. (1982) Commitment and coping in stress resistance among lawyers. Journal and Social Psychology, 42 (4), 707-717.

Kobasa, S. C. (1984). Hardiness and health: a prospective study. Journal of Personality and Social Psychology, 42 (1), 168-177.

Kreitner, Robert, \& Kinicki, A. (2014). Perilaku organisasi. Jakarta: Salemba Empat.

La Kahija,Y. F. (2017). Penelitian fenomenologis: jalan memahami pengalaman hidup. Yogyakarta: PT Kanisius.

Laksono A. D., Faizin, K., Raunsay, E., \& Soerachman, R. (2014). Perempuan Muyu dalam pengasingan. Jakarta: Balitbangkes.

Laksono A. D., Soerachman R., \& Juni, A. T. (2016). Studi kasus kesehatan maternatal suku Muyu di Distrik Mindiptana, Kabupaten Boven Digoel. Jurnal Kesehatan Reproduksi, 7( 3), 145155.

Los, R. \& Schweinle, A. (2014) The Effects of self-regulation and self- efficacy on academic outcome. Dipresentasikan pada konferensi American Psychology Association (APA), Washington.

Nobakht, H. N. \& Dale, K. Y. (2018). An exploration of the roles of trauma and dissociation in mystical experiences and near-death experiences. Journal of Spirituality in Mental Health, 1-12, doi: 10.1080/19349637.2018.1439796.

Nolan, M. (2010). Kelas bersalin. Yogyakarta: Golden Books.

Pemerintah Indonesia. (2014). Peraturan Pemerintah nomor 78 tahun 2014 tentang Percepatan Pembangunan Daerah Tertinggal.

Pemerintah Indonesia. (2015). Peraturan Presiden Nomor 131 Tahun 2015 tentang Penetapan Daerah Tertinggal Tahun 2015-2019.

Pordanjani,T. R., Pordanjani, T. R., Ebrahimi, A. M., \& Doostkam, Z. (2018). Religious attitudes and psychological hardiness as predictors of stress in students life. Journal of Research on Religion \& Health, 4 (4), 21- 32.

Rahman, A. A. (2017). Sejarah psikologi dari klasik hingga modern. Depok : Rajawali Pers.

Ruml, M. F. (2016). Special section on indigenous spirituality: Introduction. Studies in Religion/ Sciences Religieuses, 45 (3), 269-272.

Salvatore, R. \& Maddi. (2002). The story of hardiness: twenty years of theorizing, research, and practice. Consulting Psychology Journal: Practice and Research, 54 (3), 175-185

Smith, J. A., Flowers, P., \& Larkin M. (2009). Interpretative phenomenological analysis. London: Sage.

Smith, A. M. \& Siti, A. B. H. (2013). Kepribadian tangguh (hardiness) pada perempuan penderita pasca stroke. Jurnal Spirits, 3 (2), 1-7.

Sulasman \& Gumilar. (2013). Teori-teori kebudayaan: dari teori hingga aplikasi. Bandung: CV Pustaka Setia. 
Widyarini. (2014). Empat Faktor Kecerdasan Budaya Untuk Meningkatkan Ketrampilan Interpersonal. Diunduh pada 15 September 2018. 